\title{
INFLUENCE OF CHEMICAL ADDITIVES AND CURING CONDITIONS ON THE MECHANICAL PROPERTIES AND CARBONATION RESISTANCE OF ALKALI-ACTIVATED SLAG COMPOSITES
}

\author{
VPLIV KEMIJSKIH DODATKOV IN POGOJEV SUŠENJA NA \\ MEHANSKE LASTNOSTI IN ODPORNOST NA KARBONACIJO Z \\ ALKALIJAMI AKTIVIRANIH KOMPOZITOV ŽLINDRE
}

\author{
Pavel Bulejko', Vlastimil Bílek Jr.2 \\ ${ }_{1}^{1}$ Brno University of Technology, Faculty of Mechanical Engineering, Heat Transfer and Fluid Flow Laboratory, Technická 2896/2, \\ 61669 Brno, Czech Republic \\ ${ }^{2}$ Brno University of Technology, Faculty of Chemistry, Material Research Centre, Purkyňova 118, 61200 Brno, Czech Republic \\ pavel.bulejko@vut.cz \\ Prejem rokopisa - received: 2015-07-01; sprejem za objavo - accepted for publication: 2016-01-27
}

doi:10.17222/mit.2015.185

The main aim of the presented work is to investigate the effect of the addition of air-entraining (AEA) and shrinkage-reducing agents (SRA) on the mechanical properties and carbonation resistance of alkali-activated slag (AAS). The materials used for the sample preparation were blast-furnace slag activated using sodium silicate and AEA or SRA in various amounts. The samples were cured in various conditions (air curing under laboratory conditions and water curing at the same temperature) and the influence of these was also studied. The prepared samples (specimens with dimensions of $100 \mathrm{~mm} \times 20 \mathrm{~mm} \times 20 \mathrm{~mm}$ ) were tested for compressive and bending strengths. The experimental results show that the addition of AEA did not have a significant influence on the mechanical properties, while the addition of SRA had a negative effect. However, the carbonation resistance markedly decreases with an increase of both agents. The same is true for air curing, as mechanical strengths are lower compared to those samples cured in water, and the ratio of the strength of the air-cured composite and that of the water-cured composite decreases with an increase in the content of SRA.

Keywords: alkali-activated slag, carbonation resistance, chemical additives, mechanical properties

\begin{abstract}
Glavni namen tega dela je preiskava vpliva dodatka za zmanjšanje vsebnosti zraka (angl. AEA) in dodatka za zmanjšanje krčenja (angl. SRA) na mehanske lastnosti in odpornost na karbonacijo z alkalijami aktivirane žlindre (angl. AAS). Materiali za pripravo vzorcev so bili plavžna žlindra, aktivirana z natrijevim silikatom in različnim dodatkom AEA ali SRA. Vzorci so bili strjeni pri različnih pogojih (strjevanje na zraku v laboratorijskih pogojih in strjevanje v vodi pri enaki temperaturi) in študiran je bil njihov vpliv. Pripravljeni vzorci, z merami $100 \mathrm{~mm} \times 20 \mathrm{~mm} \times 20 \mathrm{~mm}$, so bili preizkušeni na tlačno in upogibno trdnost. Rezultati preiskav kažejo, da dodatek AEA ni imel pomembnega vpliva na mehanske lastnosti, medtem ko je dodatek SRA nanje vplival negativno. Vendar pa se je odpornost na karbonacijo močno zmanjšala z večanjem vsebnosti obeh dodatkov. Enako velja za strjevanje na zraku, saj so mehanske lastnosti slabše v primerjavi z vzorci, strjenimi v vodi in se razmerje trdnosti vzorcev strjenih v vodi in razmerje trdnosti na zraku strjenih kompozitov, zmanjša s povečanjem vsebnosti SRA.

Ključne besede: $\mathrm{z}$ alkalijami aktivirana žlindra, odpornost na karbonacijo, kemijski dodatki, mechanske lastnosti
\end{abstract}

\section{INTRODUCTION}

AAS has received increasing attention as a potential alternative to Portland cement (PC) due to its high strength, durability and low environmental impact. ${ }^{1-3}$ Many studies have been carried out on AAS to determine its microstructure characterization, ${ }^{4,5}$ reaction kinetics, ${ }^{6,7}$ and chemical resistance..$^{8,9}$ Additionally, the thermodynamic modelling of AAS cements ${ }^{10}$ and the phenomenon of AAS composite shrinkage ${ }^{11-14}$ have been studied. The latter has a negative effect on AAS properties, especially in terms of mechanical strength. ${ }^{15,16}$ Therefore, many chemical and mineral admixtures have recently been introduced to this area.

Chemical additives, especially those that are organic based, have recently been added to PC concrete with positive results. In addition to the commonly known application of superplasticizers, shrinkage-reducing agents (SRA) and air-entraining agents (AEA) have recently been gaining interest. SRAs are able to decrease the surface tension of water in concrete pores, which decreases the capillary tension within the pore structure. This is why shrinkage is reduced when water evaporates. Such SRAs are primarily based on polypropylene glycol. ${ }^{17}$ The main reason for introducing an AEA is to produce air bubbles dispersed throughout the concrete. This provides durability to the hardened concrete during frost-thaw cycling. The AEA is a surfactant with a structure consisting of hydrophilic and hydrophobic groups, ${ }^{18}$ based on a soluble salt of an alkyl aryl sulphonate. ${ }^{19,20}$ After adding AEA into a cement paste, AEA molecules are quickly adsorbed into the interface of the cementwater-air system. The adsorption of surfactant causes a significant reduction of the free energy from the system, 
thus making a large number of small, closed, uniform bubbles. As the cement particles are now separated, the frictional resistance among them is reduced, thus increasing the workability of the mixture. Conversely, a higher amount (generally more than $0.004 \%$ of mass fractions) of AEA cannot improve the fluidity of the mixture because the free water content in the unit volume paste decreases, causing a workability loss. ${ }^{18}$ SRAs and AEAs do not only influence the aforementioned properties, as most of these agents are primarily determined to be used in PC-based systems. These agents may increase the porosity ${ }^{21}$ and thus influence the compressive and bending strengths. Another important issue is the carbonation of AAS composites. Together with various curing conditions, the final material behaviour may be completely different. The main aim of this work is to study the influence of additives and curing conditions on the mechanical properties and the ability to resist the carbonation of an AAS composite.

\section{EXPERIMENTAL PART}

\subsection{Materials}

Ground, granulated blast-furnace slag with a specific surface of $380 \mathrm{~m}^{2} \mathrm{~kg}^{-1}$ was used as a raw material. A liquid sodium silicate was used as an alkaline activator. The activator consisted of $47 \%$ of dry matter, i.e., $16.8 \%$ of $\mathrm{Na}_{2} \mathrm{O}$ and $30.2 \%$ of $\mathrm{SiO}_{2}$, thus providing an $\mathrm{SiO}_{2} / \mathrm{Na}_{2} \mathrm{O}$ molar ratio of 1.85 . The phase composition of the slag was determined using a PANalytical Empyrean X-ray diffraction (XRD) spectrometer. The slag consists predominantly of an amorphous phase with a smaller amount of crystalline mellilite and merwinite. Granulometric measurements to determine the particle size distribution were performed with a Sympatec HELOS KR laser analyser with a measurement range between $0.1 \mu \mathrm{m}$ and $1.500 \mu \mathrm{m}$. The particle-size distribution is shown in Figure 1. The median particle size is $8.45 \mu \mathrm{m}$.

Chryso ${ }^{\circledR}$ Air A was used as an AEA. It is a commercially available chemical agent based on sulphonic acids and coconut oil, with the reaction products diethanolamine and sodium thiocyanate. Chryso ${ }^{\circledR}$ Serenis was

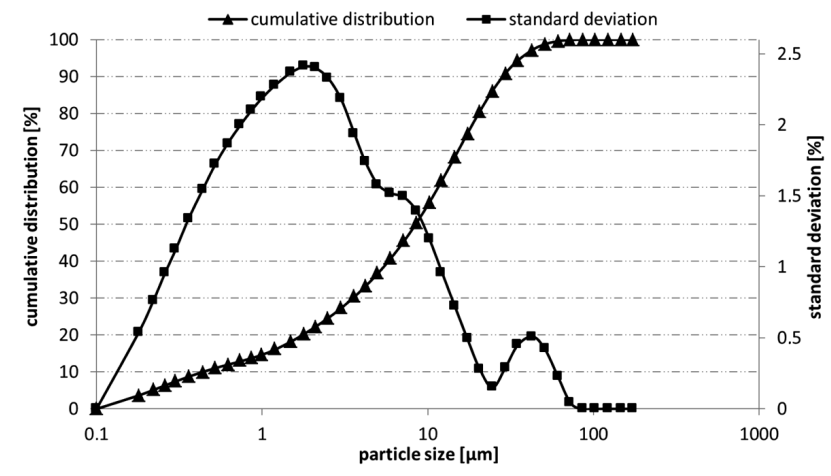

Figure 1: Particle size distribution of blast-furnace slag Slika 1: Razporeditev velikosti delcev plavžne žlindre used as a shrinkage inhibitor (SRA). This additive is based on 2-methyl-2,4-pentanediol. Both are generally used for PC-based systems.

\subsection{Composition of mortars and specimens preparation}

Mortars were prepared by mixing the blast-furnace slag with an activating solution and sand. The amount of sodium silicate was $4.2 \%$ by weight of slag. Standard fine sand as defined by CSN EN $1961^{22}$ was used as an aggregate. The slag-to-sand ratio and water-to-slag ratio of all the prepared mortars were 0.50 and 0.40 , respectively. The mortars were subsequently modified by the addition of SRA in the amount of $0.25 \%, 0.50 \%$, $1.00 \%$ and $2.00 \%$ by weight of slag. Finally, two mixtures were also modified with AEA in the amounts of $0.10 \%$ and $0.50 \%$ by mass of slag. The mortars were then cast into steel molds, demolded after $24 \mathrm{~h}$, submerged in water for $3 \mathrm{~d}$ and then stored in air under ambient conditions until the 28th day. They were then tested. The other samples (with the same composition) were cured and submerged in water for the entire time. These were then compared with those cured in air.

\subsection{Strength testing, carbonation and morphology}

Compressive and bending strengths were tested on mortar specimens, with measurements of $20 \mathrm{~mm} \times$ $20 \mathrm{~mm} \times 100 \mathrm{~mm}$, after 28 days. At least three samples of each composition were taken for a three-point bending test and the remaining parts of broken specimens were used for measurements of the compressive strength.

The depth of carbonation was determined on freshly broken specimens by spraying $1.0 \%$ phenolphthalein solution on the fracture surface of the prism. The carbonation depth was measured and the sprayed cross-section surface photographed.

The microstructure of the selected AAS pastes was investigated using a ZEISS EVO LS 10 scanning electron microscope in the secondary-electron mode at a magnification of $1000 \times$ and an accelerating voltage of $10 \mathrm{kV}$. Gold sputter-coated fracture surfaces of air-cured Ref. and SRA1.00 pastes at the age of $28 \mathrm{~d}$ were examined using this technique.

\section{RESULTS AND DISCUSSION}

The flexural and compressive strengths of tested samples with various amounts of additives are shown in Figure 2. In Figure 3, the strengths are displayed relative to the strengths of the samples cured for $28 \mathrm{~d}$ submerged in water (samples submerged in water $=100 \%$ strength, e.g. the reference water-cured mortar had approximately $121 \mathrm{MPa}^{23}$ Generally, the curing of samples submerged in water led to higher values of compressive and bending strengths, which corresponds to the work of F. Collins and J. G. Sanjayan. ${ }^{24}$ This is why the plotted values of air-cured samples are also 


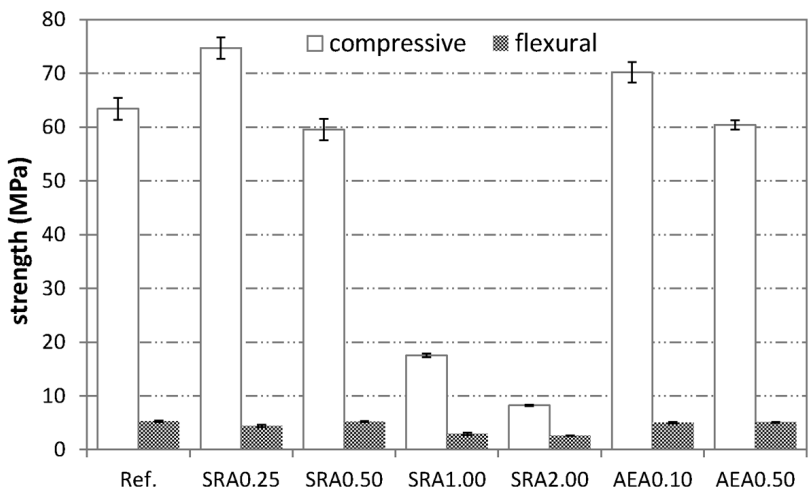

Figure 2: Compressive and flexural strengths of the prepared aircured mortars

Slika 2: Tlačna in upogibna trdnost pripravljenih, na zraku sušenih malt

displayed relative to those cured in water. The curing of the specimens submerged in water permits their flexural and compressive strength development. It is also likely that surface cracking, which is often visible on AAS specimens, could serve as a crack initiator, leading to the propagation of major shrinkage cracks. Consequently, this significantly contributes to the decrease in flexural strengths.

The reduction of flexural strength is highest in the samples with $1 \%$ and $2 \%$ of SRA. The same is true for compressive strengths. With a lower content of SRA $(0.25 \%$ and $0.50 \%)$, the reduction of strengths is lower than that of the reference sample without additives. In all the samples with SRA, the decrease of flexural strengths is lower compared to the compressive strengths, except for the sample with $0.25 \%$ of SRA. This can be related to shrinkage. With a higher SRA content, the shrinkage and cracking during sample aging in air is reduced. However, a larger amount of SRA (in this study higher than $0.50 \%$ ) has a negative effect on the compressive strength. Therefore, sample SRA0.25 has a higher relative compressive strength than bending because the amount of SRA is such that it has no effect on the shrinkage and does not negatively influence the com-

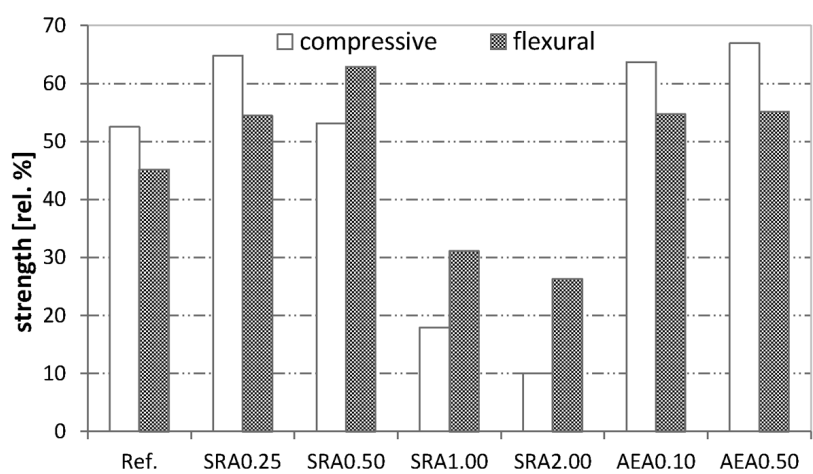

Figure 3: Relative compressive and flexural strengths (mortars cured in water $=100 \%$ )

Slika 3: Relativne tlačne in upogibne trdnosti (malta strjena v vodi $=100 \%$ )

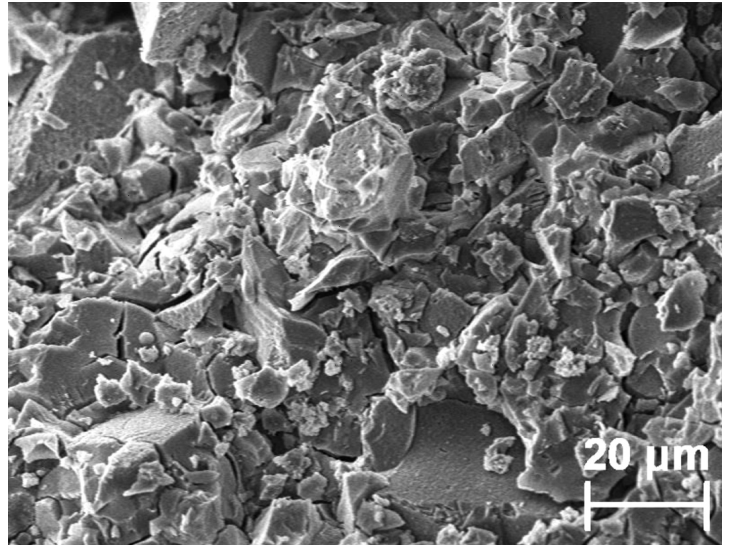

Figure 4: SEM picture of air-cured reference pastes

Slika 4: SEM-posnetek na zraku strjene referenčne paste

pressive strengths at the same time. The rapid reduction of strengths with the addition of SRA of $1 \%$ and higher is further explained by the SEM images. Figure 4 and Figure 5 show the SEM picture of the fracture surface of the reference sample and the sample with $1 \%$ of SRA, respectively. A dense matrix among the grains of slag is obvious in Figure 4, whereas in Figure 5, more porous matter among the grains of slag is observed. This also conforms to the study by V. Bílek et al. ${ }^{23}$, where the authors investigated the influence of commercially available admixtures on the drying shrinkage of AAS in relation to the mechanical properties. Finally, the samples containing AEA had the highest relative compressive strengths (with AEA0.50 as the highest).

The carbonation depth reached $2.19 \mathrm{~mm}$ for SRA0.5 (Figure 7a) while SRA1.00 and SRA2.00 were completely carbonated (Figure 7b) after $28 \mathrm{~d}$. Therefore the carbonation depths for SRA1.00 and SRA2.00 are not shown in Figure 6. According to V. Bílek et al.,23 SRA likely acts as a hydration retardant. When the samples with a higher amount of SRA are cured in air, they lose significant amounts of water before they mature. Therefore, they contain a lower amount of binding phase, which is associated with higher porosity and

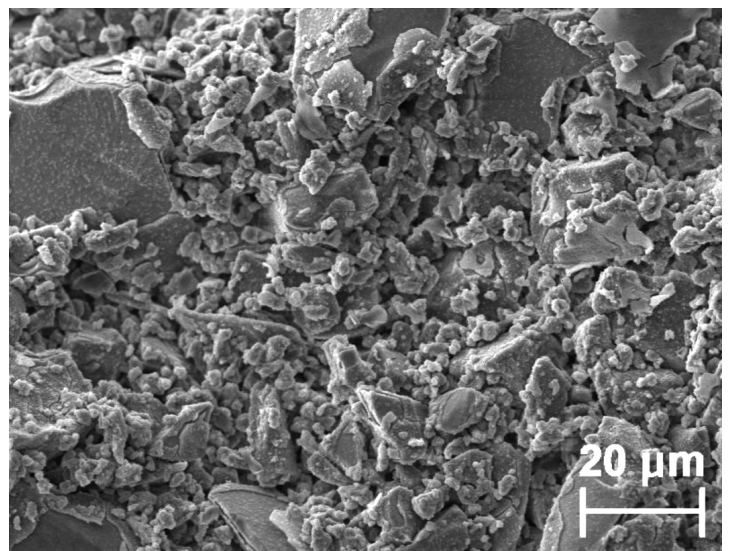

Figure 5: SEM picture of air-cured SRA1.00 paste Slika 5: SEM-posnetek na zraku strjene SRA1.00 paste 
P. BULEJKO, V. BÍLEK: INFLUENCE OF CHEMICAL ADDITIVES AND CURING CONDITIONS ...

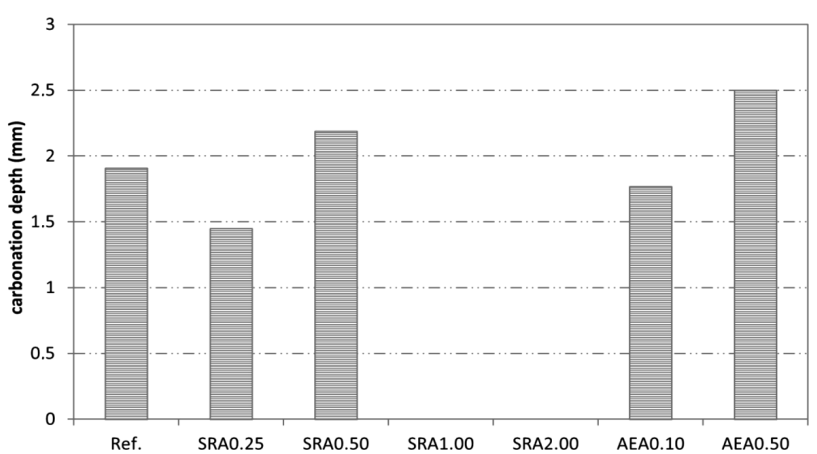

Figure 6: Carbonation depth of the prepared mortars Slika 6: Globina karbonacije pripravljenih malt

thus faster carbonation. This is another reason for their low strengths.

Some of the results obtained, especially those for carbonation resistance, are inconsistent with those reported earlier. C. Bilim et al. ${ }^{25}$ did not observe a significant difference in the carbonation depth of the samples with and without SRA activated by solid sodium silicate. When C. Bilim et al. ${ }^{26}$ used liquid sodium silicate, the carbonation resistance of AAS mortars was even better in the presence of SRA. These differences are caused by the different composition of the mixtures (particularly the $\mathrm{SiO}_{2}$ to $\mathrm{Na}_{2} \mathrm{O}$ ratio of the activator) and are most likely due to the different origins of the additives used. Bilim et al. used SRA based on polypropylene glycol in both aforementioned studies ${ }^{25,26}$, while the SRA used in the present study was based on 2-methyl-2,4-pentanediol. This indicates a strong dependence in the behaviour of AAS on the composition of commercially

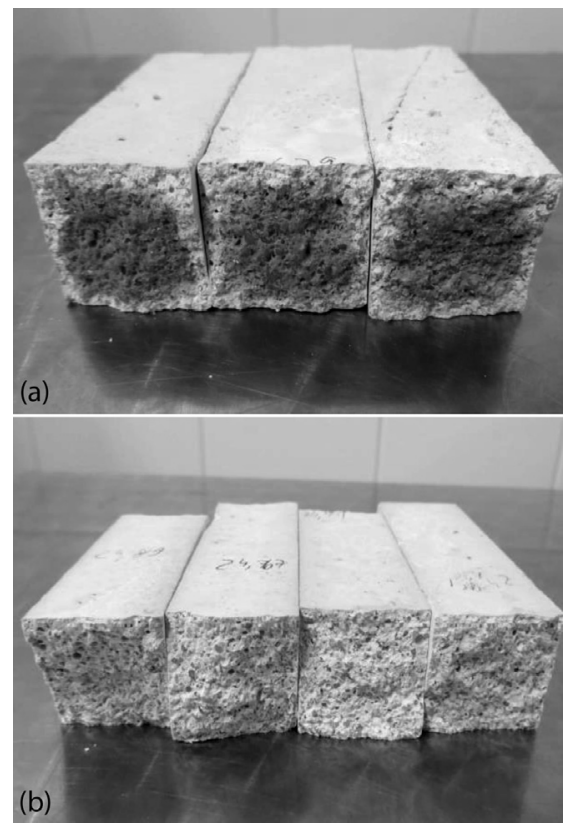

Figure 7: Carbonation of sample: a) SRA0.5 with carbonation depth of $2.19 \mathrm{~mm}$ and b) SRA1.0 completely carbonated

Slika 7: Karbonacija vzorcev: a) SRA0.5, z globino karbonacije 2,19 $\mathrm{mm}$ in b) SRA1.0 popolnoma karboniran available SRAs originally developed for PC-based systems.

\section{CONCLUSION}

Based on the results above, the conclusions can be summarized as follows:

- It was confirmed that curing by submerging in water is better for AAS than air curing in ambient laboratory conditions. The compressive and flexural strengths significantly decreased in all samples.

- When the content of admixtures was low, the reduction in strengths was slightly lower compared to the reference sample with no additive, while with a higher amount of SRA, the reduction in strengths was significantly higher.

- The incorporation of more than $0.5 \%$ of SRA led to a rapid carbonation of AAS, which is likely related to the negative effect of SRA on AAS hydration and the resulting porous matrix.

\section{Acknowledgement}

This work is an output of the research and scientific activities of project LO1202 and the project Materials Research Centre at FCH BUT - Sustainability and Development, REG LO1211, with financial support of the MEYS under the programme NPU I.

\section{REFERENCES}

${ }^{1}$ M. Chi, Effects of dosage of alkali-activated solution and curing conditions on the properties and durability of alkali-activated slag concrete, Construction and Building Materials, 35 (2012), 240-245, doi:10.1016/j.conbuildmat.2012.04.005

${ }^{2}$ W. Zhang, Y. Hama, S. H. Na, Drying shrinkage and microstructure characteristics of mortar incorporating ground granulated blast furnace slag and shrinkage reducing admixture, Construction And Building Materials, 93 (2015), 267-277, doi:10.1016/j.conbuildmat. 2015.05.103

${ }^{3}$ E. Crossin, The greenhouse gas implications of using ground granulated blast furnace slag as a cement substitute, Journal of Cleaner Production, 95 (2015), 101-108, doi:10.1016/j.jclepro.2015.02.082

${ }^{4}$ Y. Gu, Y. Fang, D. You, Y. Gong, C. Zhu, Properties and microstructure of alkali-activated slag cement cured at below- and about-normal temperature, Construction and Building Materials, 79 (2015), 1-8, doi:10.1016/j.conbuildmat.2014.12.068

${ }^{5}$ L. Y. Yang, Z. J. Jia, Y. M. Zhang, J. G. Dai, Effects of nano-TiO2 on strength, shrinkage and microstructure of alkali activated slag pastes, Cement and Concrete Composites, 57 (2015), 1-7, doi:10.1016/ j.cemconcomp.2014.11.009

${ }^{6}$ B. S. Gebregziabiher, R. Thomas, S. Peethamparan, Very early-age reaction kinetics and microstructural development in alkali-activated slag, Cement and Concrete Composites, 55 (2015), 91-102, doi:10.1016/j.cemconcomp.2014.09.001

${ }^{7}$ X. Gao, Q. L. Yu, H. J. H. Brouwers, Reaction kinetics, gel character and strength of ambient temperature cured alkali activated slag-fly ash blends, Construction and Building Materials, 80 (2015), 105-115, doi:10.1016/j.conbuildmat.2015.01.065

${ }^{8}$ M. Komljenović, Z. Baščarević, N. Marjanović, V. Nikolić, External sulfate attack on alkali-activated slag, Construction and Building Materials, 49 (2013), 31-39, doi:10.1016/j.conbuildmat.2013.08.013 


\section{MATERIALI IN TEHNOLOGIJE/MATERIALS AND TECHNOLOGY (1967-2017) - 50 LET/50 YEARS}

\section{P. BULEJKO, V. BÍLEK: INFLUENCE OF CHEMICAL ADDITIVES AND CURING CONDITIONS ...}

${ }^{9}$ I. Ismail, S. A. Bernal, J. L. Provis, R. San Nicolas, D. G. Brice, A. R. Kilcullen, S. Hamdan, J. S. J. van Deventer, Influence of fly ash on the water and chloride permeability of alkali-activated slag mortars and concretes, Construction and Building Materials, 48 (2013), 1187-1201, doi:10.1016/j.conbuildmat.2013.07.106

${ }^{10}$ R. J. Myers, B. Lothenbach, S. A. Bernal, J. L. Provis, Thermodynamic modelling of alkali-activated slag cements, Applied Geochemistry, 61 (2015), 233-247, doi:10.1016/j.apgeochem.2015. 06.006

${ }^{11}$ J. J. Thomas, A. J. Allen, H. M. Jennings, Density and water content of nanoscale solid C-S-H formed in alkali-activated slag (AAS) paste and implications for chemical shrinkage, Cement and Concrete Research, 42 (2012), 377-383, doi:10.1016/j.cemconres.2011.11.003

${ }^{12}$ X. Yuan, W. Chen, Z. Lu, H. Chen, Shrinkage compensation of alkali-activated slag concrete and microstructural analysis, Construction and Building Materials, 66 (2014), 422-428, doi:10.1016/ j.conbuildmat.2014.05.085

${ }^{13}$ N. K. Lee, J. G. Jang, H. K. Lee, Shrinkage characteristics of alkaliactivated fly ash/slag paste and mortar at early ages, Cement and Concrete Composites, 53 (2014), 239-248, doi:10.1016/ j.cemconcomp.2014.07.007

${ }^{14}$ C. D. Atiş, C. Bilim, Ö. Çelik, O. Karahan, Influence of activator on the strength and drying shrinkage of alkali-activated slag mortar, Construction and Building Materials, 23 (2009), 548-555, doi:10.1016/j.conbuildmat.2007.10.011

${ }^{15}$ F. Collins, J. G. Sanjayan, Strength and shrinkage properties of alkali-activated slag concrete placed into a large column, Cement and Concrete Research, 29 (1999), 659-666, doi:10.1016/S00088846(99)00011-3

${ }^{16}$ F. Jin, K. Gu, A. Al-Tabbaa, Strength and drying shrinkage of reactive $\mathrm{MgO}$ modified alkali-activated slag paste, Construction and Building Materials, 51 (2014), 395-404, doi:10.1016/j.conbuildmat. 2013.10.081

${ }^{17}$ M. Palacios, F. Puertas, Effect of superplasticizer and shrinkagereducing admixtures on alkali-activated slag pastes and mortars, Cement and Concrete Research, 35 (2005), 1358-1367, doi:10.1016/ j.cemconres.2004.10.014
${ }^{18}$ B. Ma, W. Huixian., Rheological properties of self-compacting concrete paste containing chemical admixtures, Journal Of Wuhan University Of Technology-Mater. Sci. Ed. 28 (2013), 291-297, doi:10.1007/s11595-013-0681-x

${ }^{19}$ T. Bakharev, J. G. Sanjayan, Y. B. Cheng, Effect of admixtures on properties of alkali-activated slag concrete, Cement and Concrete Research, 30 (2000), 1367-1374, doi:10.1016/j.cemconres.2004. 10.014

${ }^{20}$ A. M. Rashad, A comprehensive overview about the influence of different additives on the properties of alkali-activated slag - A guide for Civil Engineer, Construction and Building Materials, 47 (2013), 29-55, doi:10.1016/j.conbuildmat.2013.04.011

${ }^{21}$ J. Saliba, E. Rozière, F. Grondin, A. Loukili, Influence of shrinkagereducing admixtures on plastic and long-term shrinkage, Cement and Concrete Composites, 33 (2011), 209-217, doi:10.1016/ j.cemconcomp.2010.10.006

${ }^{22}$ ČSN EN 196-1:2005, Methods of testing cement - Part 1: Determination of strength 2005

${ }^{23}$ V. Bílek Jr., L. Kalina, J. Koplík, R. Novotný, M. Hajdúchová, T. Opravil, Influence of chemical admixture on properties of alkali-activated slag-based mortars, Advanced Materials Research, 1124 (2015), 37-42, doi:10.4028/www.scientific.net/AMR.1124.37

${ }^{24}$ F. Collins, J. G. Sanjayan, Cracking tendency of alkali-activated slag concrete subjected to restrained shrinkage, Cement and Concrete Research, 30 (2000), 791-798, doi:10.1016/S0008-8846(00)00243-X

${ }^{25}$ C. Bilim, O. Karahan, C.D. Atiş, S. Ílkentapar, Effects of chemical admixture and curing conditions on some properties of alkali-activated cementless slag mixtures, KSCE Journal of Civil Engineering, 19 (2015), 733-741, doi:10.1007/s12205-015-0629-0

${ }^{26}$ C. Bilim, O. Karahan, C.D. Atiş, S. Ílkentapar, Influence of admixtures on the properties of alkali-activated slag mortars subjected to different curing conditions, Materials and Design, 44 (2013), 540-547, doi:10.1016/j.matdes.2012.08.049 